\title{
PROGNOSTIC FACTORS IN EPITHELIAL OVARIAN CARCINOMA: A REFERENCE INSTITUTION EXPERIENCE
}

\author{
Tufan ÖGE, S. Sinan ÖZALP, Ömer T. YALÇIN
}

Department of Obstetrics and Gynecology, Osmangazi University School of Medicine, Eskisehir, Turkey

\begin{abstract}
SUMMARY
Aim: To evaluate epidemiologic and prognostic factors of the patients with epithelial ovarian cancer retrospectively and to investigate the factors that effect overall survival.

Material and methods: Between January 1990 and December 2004, 149 patients with malign epithelial ovarian tumor were included to this study. Age, parity, primary complaint and postoperative histopathology, surgical stage and maximal diameter of residual tumor of the patients were obtained and factors that effect overall survival were evaluated.

Results: Mean age of the patients was $52.8 \pm 13$ years. Most of the patients were multipar (85.9\%) and most fruquent (n: 88) (59.1\%) complaint was abdominal swelling. Postoperative surgical stages were stage I in 24 (16.1\%), stage II in11 (7.4\%), stage III in 87 (58.4\%) and stage IV in 27 (18.1\%) patients. Maximal diameter of residual tumor was <1 cm in 68 patients (45.6\%), $\geq 1 \mathrm{~cm}$ in 57 patients (38.3\%) while there was no residual tumor in 24 patients (16.1\%). Histopathologic cell types distributed as: serous (53.6\%), endometrioid (16.7\%), musinous (10.7\%), clear cell (10.7\%), others (7.8\%). The patinets $<65$ years old had similar overall survival compared to those who were $\geq 65$ years old ( $p>0.05$ ). The mean overall survival of the patients with maximal residual tumor size $\leq 1 \mathrm{~cm},>1 \mathrm{~cm}$ and no residual tumor were obtained to be 54.8 months, 22.7 months and 43.5 months respectively ( $<<0.001)$. According to the surgical stages I,II,III and IV mean survival was 78.5 months, 60.1 months, 33.9 months and 16.1 months respectively and significantly different $(p<0.001)$.

Conclusion: The data of the study revealed that surgical stage and postoperative maximum residual tumor diameter had significantly effect on overall survival where it was not effected by the age of the patients in epitelial ovarian cancers. So, early diagnosis and optimal cytoreduction should be attemped to improve the prognosis of the patients.
\end{abstract}

Key words: epidemiologic factors, epithelial ovarian cancer, prognosis

Journal of Turkish Society of Obstetrics and Gynecology, (J Turk Soc Obstet Gynecol), 2011; Vol: 8 Issue: 1 Pages: $51-6$

ÖZET

\section{EPITTELİAL OVER KANSERLERINDE PROGNOSTIKK FAKTÖRLER: BİR REFERANS MERKEZININ DENEYIMI}

Amaç: Over kanserli vakaları retrospektif olarak inceleyerek, epidemiyolojik ve prognostik faktörleri araştırmak ve sağkalıma etki eden parametreleri incelemek.

Gereç ve yöntemler: Ocak 1990 - Aralık 2004 tarihleri arasında kliniğimizde takibi yapılan 149 malign epitelial over tümörlü vaka incelendi. Hastaların yaşı, paritesi, primer şikayetleri, postoperatif tümör histopatolojileri, cerrahi evreleri ve maksimum rezidü tümör çapları kayıt edilerek bu parametlerin să̆kalımlarına etkisi değerlendirilmiştir. Bulgular: Hastaların ortalama tanı yaşı $52.8 \pm 13$ yıl olarak saptanmıştır. Olguların büyük çoğunluğu (\%85.9) multipar olup, en sık şikayet (n: $88 \% 59.1$ ) karın şişliği olarak tespit edilmişstir. Cerrahi sonrası hastaların 24'ü

Address for Correspondence: Dr. Tufan Öge. Esmangazi Üniversitesi Tıp Fakültesi, Kadın Hastalıkları ve Doğum ABD, 26480 Eskişehir, Turkey Phone.: +90 (222) 2292002

e-mail: tufanoge@yahoo.com

Received: 20 January 2010, revised: 11 October 2010, accepted: 12 November 2010, online yayın tarihi: 15 December 2010 
(\%16.1) evre I, 11'i (\%7.4) evre II, 87'si (\%58.4) evre III ve 27'si (\%18.1) evre IV ve rezidü tümör çaplarl, maksimum $1 \mathrm{~cm}$ olan 68 (\%45.6), $1 \mathrm{~cm}$ ve üzerine olan 57 hasta (\%38.3) saptanmış, 24 hastada ise (\%16.1) rezidü tümör kalmadığ saptanmıştır. Histopatolojik olarak: seröz (\%53.6), endometrioid (\%16.7), müsinöz (\%10.7), berrak hücreli (\%10.7), diğer (\% 7.8) tespit edilmiștir. Yaşı < 65 olan hastaların să̆kalımlarının yaşı $\geq 65$ olanlarla benzer olduğu belirlenmiştir (p>0.05). Postoperatif rezidü tümörü kalmayan grupta ortalama yaşam süresi 43.5 ay bulunurken, 1 cm'nin altı ve $1 \mathrm{~cm}$ 'nin üstünde tümör kalan gruplarda ise ortalama yaşam süresi sirastyla 54.8 ve 22.7 ay olarak bulunmuştur. $($ < 0.001$)$. Hastaların evrelerine göre ortalama yaşam süreleri evre I, evre II, evre III ve evre IV'de sirasiyla 78.5 , 60.1 , 33.9 ve 16.1 ay olarak tespit edilmiştir $(p<0.001)$.

Sonuç: Araştırmamızda yaşın prognoz üzerine önemi saptanmazken, evre ve postoperatif rezidü tümör çapı sağkalıma etki eden faktörler olarak saptanmıştır. Hastaların daha iyi prognozu için over kanserini erken evrede yakalamak ve opere edilen olgularda rezidü tümör çapını maksimum derecede küçültmek hedeflenmelidir.

Anahtar kelimeler: epidemiyolojik faktörler, epitelial over kanseri, prognoz

Türk Jinekoloji ve Obstetrik Derneği Dergisi, (J Turk Soc Obstet Gynecol), 2011; Cilt: 8 Sayl: 1 Sayfa: 51- 6

\section{INTRODUCTION}

In women, ovarian cancer is the fifth most common cancer, it is the second most common one among the gynecologic cancers, and the most common cause of gynecologic cancer deaths $(1,2)$. The incidence of ovarian cancer increases with age, and the average age at diagnosis is 63 . The highest incidence is in the age group of 75-79(2). ovarian cancer symptoms might not be seen for a long time in the vast majority of women. Most of the time developing symptoms are not specific. For this reason, they are often at an advanced stage when they are diagnosed ${ }^{(3)}$. surgical staging is being performed in ovarian cancer, and since the stage has a great effect on the prognosis staging laparotomy is of great importance ${ }^{(4)}$. Treatment depends on the stage of the patient following primary surgery. The main purpose is surgically removing the maximum amount of tumor and leaving no tumor behind, because there is a significant relationship between the residual tumor volume and survival( ${ }^{(5)}$.

The purpose of this study is to review the cases of epithelial ovarian cancer retrospectively and to investigate the epidemiological and prognostic factors, to examine the parameters influencing the survival.

\section{MATERIALS AND METHODS}

In this research 149 cases among the 289 cases of malignant ovarian tumor with a planned treatment, that were diagnosed in Eskisehir Osmangazi University School of Medicine, Department of Obstetrics and
Gynecology, Gynecologic Oncology Unit during the period of January 1990 and December 2004, whose file and prognostic information were approachable were included and permission was provided from University Research Ethics Board with a date of 28/09/2006 and sequence number of 07. After the information of the patients were provided from the patient files and operation book they were evaluated retrospectively. During these evaluation age of the patient, parity and complaints were recorded. Staging laparotomy was performed after the preoperative evaluation. With a preferred vertical midline incision during the first attempt acid fluid was taken. When there was no acid fluid sample for cytologic examination was obtained by washing. All the intra-abdominal organs such as the lower side of diaphragm, liver surface, small intestine and colon was palpated and biopsies were taken from suspected areas. Both ovaries, tubes, uterus and omentum were removed along with the tumor tissue that could be removed. Retroperitoneal pelvic and para-aortic lymph nodes were dissected until the level of the IMA and lymph node sampling was performed. In cases with an extensive tumor as much tumor tissue as possible was excised in order to reduce the volume of residual tumor. Pathology reports were evaluated according to FIGO staging. The postoperative pathologic diagnosis of primary ovarian cancer cases were included in the study. From the file records stage and survival of the patient were evaluated by the maximum diameter of tumor remaining after the surgery. Statistical Package for the Social Sciences (SPSS) for Windows 13.0 was used for statistical calculations and comparisons. While Kaplan-Meier 
test was used for the analysis of survival, log rank test was used for the comparison of these curves. Data were given as arithmetic mean \pm standard deviation and $p$ values of $<0.05$ was considered as statistically significant.

\section{RESULTS}

The age of the patients at diagnosis were between 1980 , and the average age was found as $52.8 \pm 13$. The most common application was in the age group of 5160 with 52 patients $(34.9 \%)$, and this was followed by $38(25.5 \%)$ and $26(17.4 \%)$ patients in the age groups of 61-70 and 41-50, respectively (Table I). When the distribution of parity was examined the vast majority of patients $(85.9 \%)$ were multiparous, in 68 patients $(45.6 \%)$ the parity was 4 or above, and in 60 of them $(40.3 \%)$ had a parity between $1-3$. The number of nulliparous patients were found 21 (14.4\%). When the patients were evaluated according to complaints at the first application abdominal swelling was found in 88 cases $(59.1 \%)$, abdominal pain in 31 patients (20.8\%), vaginal bleeding in 14 cases $(9.4 \%)$, pelvic pain in 13 patients $(8.7 \%)$ and 3 cases were asymptomatic, but during the routine gynecological examination adnexial mass was found. Following the surgery 24 patients $(16.1 \%)$ were found stage I, 11 (7.4\%) of them stage II, 87 (58.4) in stage III and 27 (18.1\%) were stage IV. In addition, small bowel resection was performed in nine patients and splenectomy was performed in three patients. Tumor implants were detected in spleen in three of the patients and in liver in seventeen of the patients, and four patients had pleural effusion. Pelvic and paraaortic lymph node metastases in stage I, II, III and IV were found as $8.3 \%$, $27.2 \%, 55.1 \%, 66.6 \%$, respectively. After the operation, no residual tumor was detected in 24 patients $(16.1 \%)$, while in 68 patients the maximum diameter of remaining residual tumor was $1 \mathrm{~cm}(45.6 \%)$, and in 57 patients it was found $1 \mathrm{~cm}$ and over $(\% 38.3)$.

Histopathological evaluation of these cases revealed the cell types as following: serous in 80 patients (53.6\%), endometrioid in 25 patients $(16.7 \%)$, mucinous in 16 cases $(10.7 \%)$, clear cell in 16 cases $(10.7 \%)$, and others in 12 patients $(7.8 \%)$.
Table I: Patient and clinicopathological features $(n=149)$.

\begin{tabular}{|c|c|c|}
\hline & $\begin{array}{l}\text { Patient number } \\
\text { (n) }\end{array}$ & $\begin{array}{l}\text { Value percent } \\
(\%)\end{array}$ \\
\hline \multicolumn{3}{|l|}{ Age } \\
\hline$<30$ & 11 & 7.3 \\
\hline $31-40$ & 14 & 9.4 \\
\hline $41-50$ & 26 & 17.4 \\
\hline $51-60$ & 52 & 34.9 \\
\hline $61-70$ & 38 & 25.5 \\
\hline $71-80$ & 8 & 5.4 \\
\hline \multicolumn{3}{|l|}{ Parity } \\
\hline 0 & 21 & 14.1 \\
\hline $1-3$ & 60 & 40.3 \\
\hline$\geq 4$ & 68 & 45.6 \\
\hline \multicolumn{3}{|l|}{ Complaint } \\
\hline Abdominal distension & 88 & 59.1 \\
\hline Abdominal pain & 31 & 20.8 \\
\hline Vaginal bleeding & 14 & 9.4 \\
\hline Groin pain & 13 & 8.7 \\
\hline Detected in control & 3 & 2.0 \\
\hline \multicolumn{3}{|l|}{ Histopathology } \\
\hline Serous & 80 & 53.6 \\
\hline Endometrioid & 25 & 16.7 \\
\hline Mucinous & 16 & 10.7 \\
\hline Clear cell & 16 & 10.7 \\
\hline Other & 12 & 1.2 \\
\hline \multicolumn{3}{|l|}{ Stage } \\
\hline I & 24 & 16.1 \\
\hline II & 11 & 7.4 \\
\hline III & 87 & 58.4 \\
\hline IV & 27 & 18.1 \\
\hline \multicolumn{3}{|c|}{ Maximum residual tumor $(\mathrm{cm})$} \\
\hline 0 & 24 & 16.1 \\
\hline$<1$ & 68 & 45.6 \\
\hline$\geq 1$ & 57 & 38.3 \\
\hline
\end{tabular}

When the patients were classified as older or younger than 65 years-old and the effect of age on survival was investigated there was no significant difference between the two groups ( $p>0.05)$ (Table II, Figure 1). According to maximum diameter of tumor left behind after the operation the median survival time in the group with no residual tumor was found 43.5 months, while in the groups with a residual tumor below $1 \mathrm{~cm}$ or over $1 \mathrm{~cm}$ the average survival time was found as 54.8 and 22.7 months, respectively, and the decreased survival time in the group with a residual tumor over $1 \mathrm{~cm}$ was statistically significant ( $<0.001$ ) (Figure 2 ). When the average survival time of patients according to the stage was evaluated the mean survival time in stage I, stage II, stage III and stage IV were 78.5 months and 60.1 months, 33.9 months and 16.1 months, respectively, and a statistically significant difference was found between the groups ( $p<0.001)$ (Figure 3 ). 
Table II: Prognositc factors affecting the average survival time.

\begin{tabular}{|c|c|c|c|}
\hline & $\begin{array}{l}\text { Average } \\
\text { survival time } \\
\text { (month) }\end{array}$ & $\begin{array}{l}\text { Standard } \\
\text { error }\end{array}$ & $\mathbf{p}$ \\
\hline \multicolumn{4}{|l|}{ Age } \\
\hline$<65$ & 41.2 & 4.2 & \\
\hline$\geq 65$ & 48.0 & 10.7 & $>0.05$ \\
\hline \multicolumn{4}{|l|}{ Stage } \\
\hline I & 78.5 & 10.8 & \\
\hline II & 60.1 & 8.9 & \\
\hline III & 33.9 & 4.2 & \\
\hline IV & 16.1 & 2.1 & $<0.001$ \\
\hline \multicolumn{4}{|c|}{ Maximum residual tumor $(\mathrm{cm})$} \\
\hline 0 & 43.5 & 6.4 & \\
\hline$<1$ & 54.8 & 6.5 & \\
\hline$\geq 1$ & 22.7 & 2.3 & $<0.001$ \\
\hline
\end{tabular}

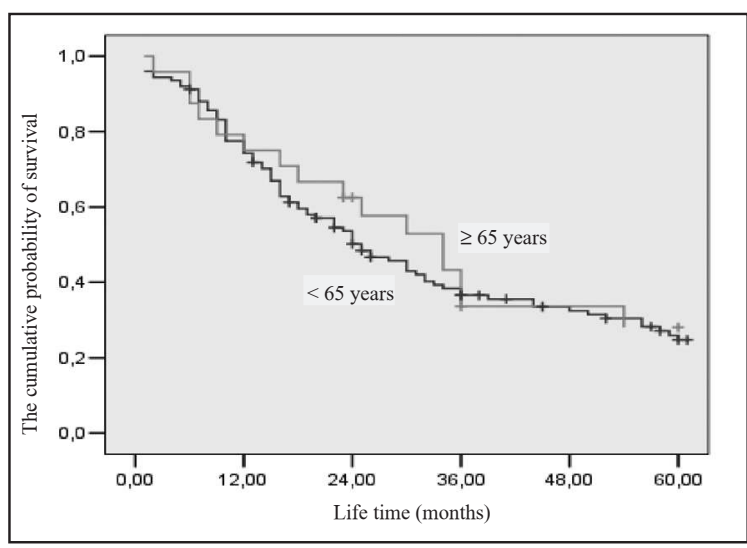

Figure 1: Survival by age groups.

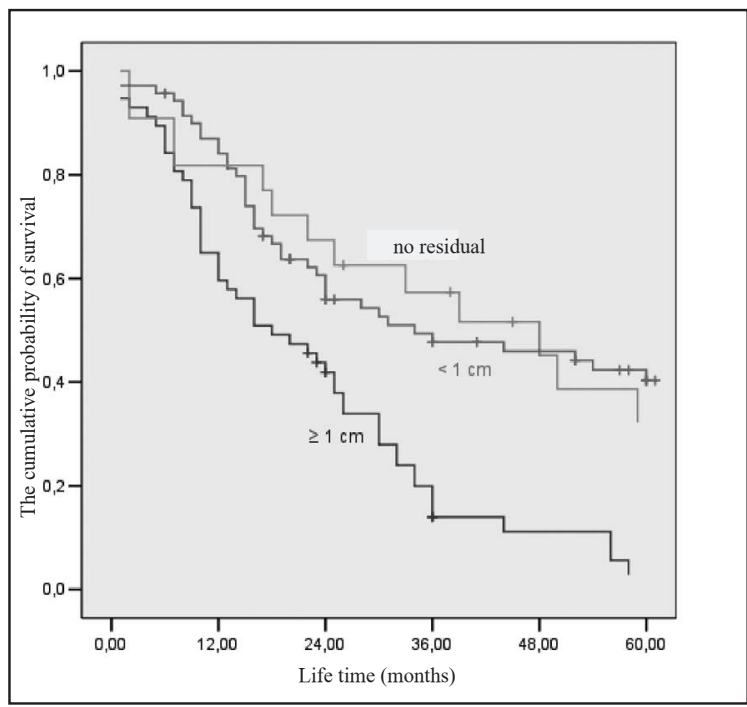

Figure 2: The maximum diameter of residual tumor according to the times.

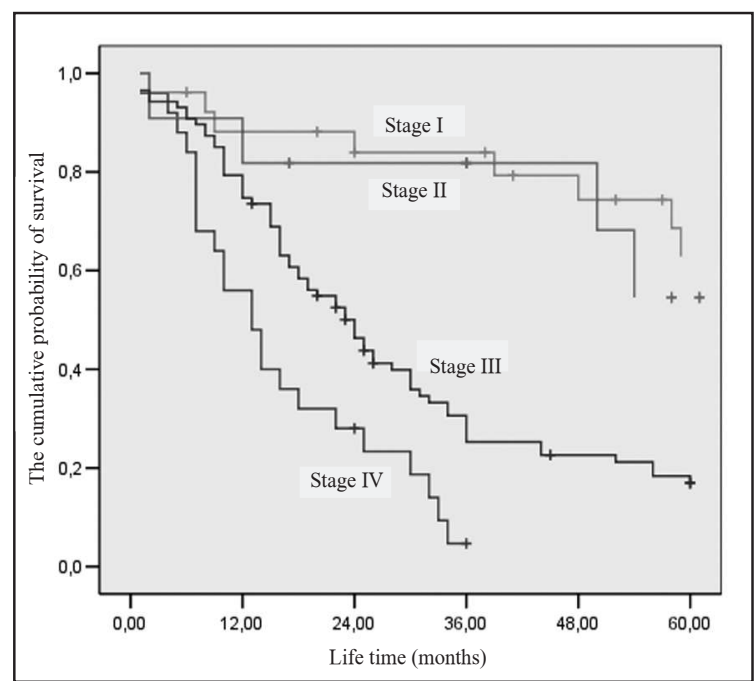

Figure 3: According to the stages of life times.

\section{DISCUSSION}

Epithelial ovarian cancer is commonly seen in perimenopausal and postmenopausal women, while the incidence of peak period is emphasized as the 60 years of age ${ }^{(6)}$. The mean age in our patients was 52 \pm 13 years and in the vast majority of cases the ages were between $51-70$ with a rate of $60.4 \%$. Scholz et $\mathrm{al}^{(7)}$ retrospectively evaluated Stage IV ovarian cancer cases and found the average age as $59.9(37-76)^{(7)}$. In another study, it was emphasized that approximately $85 \%$ of patients with ovarian cancer are over 50 years$\operatorname{old}^{(8)}$. Ovarian cancer appears to be particularly a disease of an advanced age, and it is almost hiding behind the curtain of a fog because of other diseases accompanying at this age and complaints depend on them. In our study abdominal distension was seen in $59.1 \%$ of patients and was the most common complaint which was followed by abdominal pain with a rate of $20.8 \%$. vaginal bleeding was found in $8.7 \%$, and pelvic pain was found in $8.7 \%$. In accordance with our study Olson $\mathrm{SH}$ et al.(9) also reported abdominal fullness, swelling and pressure sensation as the most commmon complaint $(71 \%)$, and the second most frequent complaint was reported as abdominal pain (52\%). These non-specific symptoms cause delays in diagnosis, thus patients are often diagnosed at an advanced stage. $16.1 \%$ of our cases were at stage I, and $7.4 \%, 58.4 \%$ and $18.4 \%$ of the patienst were at stage II, stage III and stage IV, respectively. Also in the literature the rate of stage I, II, III and IV patients were as 17-21\%, $7-10 \%, 49-52 \%$ and $20-24 \%$, respectively $(10,11)$. When 
the cases were evaluated according to the maximum diameter of residual tumor after the operation performed in our clinic , $16.1 \%$ of cases did not have remaining tumor left, $45.6 \%$ of the cases had residual tumor below $1 \mathrm{~cm}$, and $38.3 \%$ of the cases had residual tumor over $1 \mathrm{~cm}$. While the importance of the diameter of residual tumor was emphasized in the literature, when the operations were evaluated cases with a tumor diameter below $1 \mathrm{~cm}$ ranges from $33 \%$ to $67 \%(12,13)$. The cases of our clinic are consistent with the literature. In addition the need for experienced surgeons in this subject for optimal cytoreduction is emphasized and in the literature the differences in the distribution of patients were explained in this way ${ }^{(14)}$.

In our study, there was no significant effect of age on survival. Similarly, studies in the literature investigating the prognostic significance of age studied the survival time of patients as well, and emphasized that young age is an independent prognostic factor ${ }^{(15,16)}$. Another study in which only the reproductive period was evaluated revealed that age does not have a prognostic effect on survival ${ }^{(17)}$. However, the duration of survival in the geriatric group was significantly less than the group of non-elderly, and there are studies showing that even if adjusting for stage and residual disease is performed older groups have lower survival rate ${ }^{(18,19)}$. The majority of studies show that there is a larger tumor left post-operatively in older patients and that the patients have a shorter survival time. In these studies, it has been emphasized that aggressive surgery cannot be performed in the geriatric group, that is why the residual tumor diameter might be larger in size ${ }^{(18-}$ 21). In our study, while we had 125 cases under 65 years-old, we had 24 cases over 65 years-old and due to this small number of geriatric patients a meaningful conclusion could not be reached.

The studies emphasized that maximum diameter of residual tumor remaining after the operation has a prognostic value $(22,23)$. In our patients the mean survival time of patients with no residual tumor or residual tumor $<1 \mathrm{~cm}$ were similar, while the decrease in mean survival time of patients with residual tumor $1 \mathrm{~cm}$ or more was statistically significant (Figure 4.3). In the literature the definition of optimal surgery according to remaining residual tumor diameter has changed in the recent years. In 1970s $\leq 2 \mathrm{~cm}$ was sufficient for optimal surgery $(24,25)$. Afterwards, in the early 1980 s optimal surgery was defined as $\leq 3 \mathrm{~cm}$, and in the late 1980s it has been revised as $\leq 1 \mathrm{~cm}^{(26,27)}$. In accordance with our study, publications in the literature also indicate the maximum residual tumor diameter as a prognostic factor and observed that survival increases as the residual tumor size decreases $(12,13,22,23)$. In our study, although the survival time in the group with a residual tumor diameter $<1 \mathrm{~cm}$ was not statistically different, the fact that it is 11.3 months better than the group with no residual tumor could be explained by the small number of cases or with the discussion that cases with a residual tumor $<1 \mathrm{~cm}$ could be considered as optimal as well.

When the survival of the patients were evaluated according to the stage the average survival time in Stage I, II, III, and IV were 78 months, 60 months, 33 months and 16 months, respectively. Another study, in accordance with our study, stated survival diminishes as the stage advances by showing that 5-year survival rates were $72 \%$ in patients at early stage (stage I-II), and $27 \%$ in patients with advanced stages of disease (28). In another 5-year survival rates of stage I, II, III and IV were reported as $72 \%$ and $42 \%, 21 \%$ and $6 \%$, respectively, and stage was emphasized as the prognostic factor concerning the survival(10). In the literature, even though there is a consensus on decreased survival by the advanced stage, the survival times vary. In a study remarking on this variety, the mean time in the advanced cases were emphasized as 12-21 months and it was stated that ovarian cancer surgery should be performed by the gynecologic oncologists ${ }^{(29)}$.

In conclusion, stage and residual tumor size after surgery was found as the prognostic factors that influence the survival. For a better prognosis of patients, early diagnosis of ovarian cancer and in the cases operated maximum reduction in the residual tumor size should be targeted.

\section{REFERENCES}

1. Jemal A, Siegel R, Ward E, Murray T, Xu J, Smigal C, Thun MJ. Cancer statistics, 2006. CA Cancer J Clin. 2006; 56: 106- 30.

2. Permuth-Wey J, Sellers TA. Epidemiology of ovarian cancer. Methods Mol Biol 2009; 472: 413- 37.

3. Webb PM, Purdie DM, Grover S, Jordan S, Dick ML, Green AC. Symptoms and diagnosis of borderline, early and advanced epithelial ovarian cancer. Gynecol Oncol 2004; 92: 232- 9.

4. Hennessy BT, Coleman RL, Markman M. Ovarian cancer. 
Lancet 2009; 374: 1371- 82.

5. Eisenkop SM, Spirtos NM, Lin WC. "Optimal" cytoreduction for advanced epithelial ovarian cancer: a commentary. Gynrcol Oncol 2006; 103: 329- 35.

6. Yancik R. Ovarian cancer. Age contrasts in incidence, histology, disease stage at diagnosis, and mortality. Cancer 1993; 71: 517- 23.

7. Scholz HS, Benedicic C, Haas J, Tamussino K, Petru E. Stage IV ovarian cancer: prognostic factors and survival beyond 5 years. Anticancer Res 2001; 21: 3729- 32

8. Merino MJ, Jaffe G. Age contrast in ovarian pathology. Cance 1993; 71: 537- 44

9. Olson SH, Mignone L, Nakraseive C, Caputo TA, Barakat RR, Harlap S. Symptoms of ovarian cancer. Obstet Gynecol 2001; 98: 212- 7

10. Brun JL, Feyler A, Chene G, Saurel J, Brun G, Hocke C. Longterm results and prognostic factors in patients with epithelial ovarian cancer. Gynecol Oncol 2000; 78: 21- 7 .

11. Board RE, Bruijns CT, Pronk AE, Ryder WD, Wilkinson PM, Welch R,et al. Stage- and CA125-related survival in patients with epithelial ovarian cancer treated at a cancer center. Int J Gynecol Cancer 2006; 16 Suppl 1: 18- 24

12. Aletti GD, Dowdy SC, Gostout BS, Jones MB, Stanhope CR, Wilson TO, et al. Aggressive surgical effort and improved survival in advanced-stage ovarian cancer. Obstet Gynecol 2006; 107: 77- 85 .

13. Bailey J, Murdoch J, Anderson R, Weeks J, Foy C. Stage III and IV ovarian cancer in the South West of England: five-year outcome analysis for cases treated in 1998. Int J Gynecol Cancer 2006; 16 Suppl 1: 25- 9.

14. Aletti GD, Gostout BS, Podratz KC, Cliby WA. Ovarian cancer surgical resectability: relative impact of disease, patient status, and surgeon. Gynecol Oncol 2006; 100: 33- 7.

15. Bozas G, Dimopoulos MA, Kastritis E, Efstathiou E, Koutsoukou $\mathrm{V}$, Rodolakis A, et al. Young age is associated with favorable characteristics but is not an independent prognostic factor in patients with epithelial ovarian cancer: A single institution experience. Oncology 2006; 70: 265- 72 .

16. Duska LR, Chang YC, Flynn CE, Chen AH, Goodman A Fuller $\mathrm{AF}$, et al. Epithelial ovarian carcinoma in the reproductive age group. Cancer 1999; 85: 2623- 9 .

17. Massi D, Susini T, Savino L, Boddi V, Amunni G, Colafranceschi M. Epithelial ovarian tumors in the reproductive age group: age is not an independent prognostic factor. Cancer 1996; 77 : $1131-6$.
18. Berman ML. Future directions in the surgical management of ovarian cancer. Gynecol Oncol 2003; 90: S33- 9.

19. Thigpen T, Brady MF, Omura GA, Creasman WT, McGuire WP, Hoskins WJ, et al Age as a prognostic factor in ovarian carcinoma. The Gynecologic Oncology Group experience. Cancer 1993; 71: 606- 14.

20. Young RC, Brady MF, Walton LA, Homesley HD, Averette HE, Long HJ. Localized ovarian cancer in the elderly. The Gynecologic Oncology Group experience. Cancer 1993; 71: 601- 5 .

21. Bristow RE, Puri I, Chi DS. Cytoreductive surgery for recurrent ovarian cancer: A meta-analysis Gynecologic Oncology 2009; 112: $265-74$.

22. Chi DS, Eisenhauer EL, Lang J, Huh J, Haddad L, Abu-Rustum NR, Sonoda Y, Levine DA, Hensley M, Barakat RR. What is the optimal goal of primary cytoreductive surgery for bulky stage IIIC epithelial ovarian carcinoma (EOC)? Gynecol Oncol 2006.

23. Bristow RE, Montz FJ, Lagasse LD, Leuchter RS, Karlan BY. Survival impact of surgical cytoreduction in stage IV epithelial ovarian cancer. Gynecol Oncol 1999; 72: 278- 8.7

24. Bristow RE, Tomacruz RS, Armstrong DK, Trimble EL, Montz FJ. Survival effect of maximal cytoreductive surgery for advanced ovarian carcinoma during the platinum era: a meta-analysis. J Clin Oncol 2002; 20: 1248- 59

25. Hoskins WJ, McGuire WP, Brady MF, Homesley HD, Creasman WT, Berman M, Ball H, Berek JS. The effect of diameter of largest residual disease on survival after primary cytoreductive surgery in patients with suboptimal residual epithelial ovarian carcinoma. Am J Obstet Gynecol 1994; 170: 974- 9; discussion 979- 80.

26. Omura G, Blessing JA, Ehrlich CE, Miller A, Yordan E, Creasman WT, Homesley HD. A randomized trial of cyclophosphamide and doxorubicin with or without cisplatin in advanced ovarian carcinoma. A Gynecologic Oncology Group Study. Cancer 1986; 57: 1725- 30 .

27. Omura GA, Brady MF, Homesley HD, Yordan E, Major FJ, Buchsbaum HJ, Park RC. Long-term follow-up and prognostic factor analysis in advanced ovarian carcinoma: the Gynecologic Oncology Group experience. J Clin Oncol 1991; 9: 1138- 50.

28. Linasmita V, Pattaraarchachai J, Daengdeelert P. Prognostic factors for survival of epithelial ovarian cancer. Int J Gynaecol Obstet 2004; 85: 66- 9.

29. Tingulstad S, Skjeldestad FE, Halvorsen TB, Hagen B. Survival and prognostic factors in patients with ovarian cancer. Obstet Gynecol 2003; 101: 885- 91 